\title{
PALM2/AKAP2 Fusion Gene
}

National Cancer Institute

\section{Source}

National Cancer Institute. PALM2/AKAP2 Fusion Gene. NCI Thesaurus. Code C158487.

A fusion gene $(\sim 7 \mathrm{~kb})$ that results from a read-through of 2 genes in the vicinity of $9 \mathrm{q} 31.3$

which fuses the PALM2 gene to the AKAP2 gene. Variation in the fusion gene is associated with the variability in human height. 